\title{
Urban Renewal, Governance and Sustainable Development: More of the Same or New Paths?
}

Ingemar Elander (D)

Citation: Elander, I. Urban Renewal, Governance and Sustainable Development: More of the Same or New Paths? Sustainability 2022, 14, 1528. https://doi.org/10.3390/ su14031528

Received: 17 January 2022 Accepted: 20 January 2022 Published: 28 January 2022

Publisher's Note: MDPI stays neutral with regard to jurisdictional claims in published maps and institutional affiliations.

Copyright: (C) 2022 by the author. Licensee MDPI, Basel, Switzerland. This article is an open access article distributed under the terms and conditions of the Creative Commons Attribution (CC BY) license (https:// creativecommons.org/licenses/by/ $4.0 /)$.
School of Humanities, Education and Social Sciences, Örebro University, 70281 Örebro, Sweden; ingemar.elander@oru.se

Humanity seems to have been thrown into a 'perfect storm' of several huge challenges such as global warming, accelerating extinction of species, the corona pandemic and uncontrollable migration streams caused by fossil fuel emissions, overexploitation of natural resources, extreme weather, viruses, and ethnic and religious conflicts. On top of this, there are even signs that liberal democracy is in crisis, far from the days when it was proclaimed irreversibly hegemonic [1]. The challenges mentioned are, by many scientists, some world leaders and a broader audience, considered existential threats in need of urgent action, that is 'securitization' [2]. As the causes, effects and adequate reactions upon these threats are contested, there are no given solutions how to 'de-securitize' them, neither one by one, no less together. In other words, it is ultimately a question of how government and governance configurations globally, at various levels and settings, choose to decide on the road forward. Although world leaders in the Global North have been desperately fertilizing their economies with heaps of money to recover the still largely fossil-dependent 'Great Acceleration', there are in this 'critical juncture' also windows of opportunity to enter new paths. How do urban public institutions and actors in market and civil society respond to these crises? Do they only try to reinvent old ideas and practices, or do they search for healthier, more sustainable, democratic and just ways of handling major threats and risks?

There is a widening gap between current and expected development and what needs to be done in responding to climate change: 'Record atmospheric greenhouse gas concentrations and associated accumulated heat have propelled the planet into uncharted territory, with far-reaching repercussions for current and future generations' [3], The Climate Pact agreed upon at Glasgow in October 2021 ended up with representatives of the participating nations signing a deal calling for the world's major emitters of greenhouse gases to keep the key target of limiting the increase of global warming to 1.5 degrees as agreed upon in Paris 2015. However, as the increase in temperature since then has already reached 1.2 degrees, this seems unlikely, as it implies that most of the remaining oil, gas and coal reserves on earth have to remain unexploited [4]. At least the Pact promises more money for developing nations to help them adapt to the worst effects of climate change, also clarifying the rules around carbon markets. At the very end, however, India, backed by China and other coal-dependent nations, in the Global South rejected a clause calling for the 'phase out' of fossil-fired power in favor of the less demanding wording 'phase down'. The implication of that switch of one single word was met dismally by many EU countries, and in particular all small island nations, who are the most vulnerable to rising sea levels caused by climate change. As succinctly stated by the Guardian columnist George Monbiot: World leaders 'make a series of grand announcements, then convince us they have saved the planet. Words are politically cheap, actions are expensive' [5].

The multilevel handling of climate-change mitigation and adaptation reflects the complexity of this policy area. Nation-states and other actors such as trans-national companies, universities, scientific laboratories, NGOs and social movements are all important members in the choir of voices needed to phase out fossil-fired power dependency. Agreements and regulations at global, international and national levels are, indeed, important frameworks 
within which regional and local policy measures are taken, but action by public, private, and voluntary association actors may also influence policy making at, or between, various levels. Whether these actions will also have an impact on high-level, large-scale decisions is questionable, although they are certainly crucial when it comes to local climate change adaptation in relation to the consequences of extreme weather. The sheer magnitude of policy initiatives at the local level, their diversity, and the experimental and practical nature of many local projects, are bound to bring forward genuinely new ideas and solutions, but to have an overall impact, they also have to be a matter of national, international and global politics, not to forget the potential of a massive bottom-up mobilization by youth and adult climate activists in civil society.

Although we have a multi-level governance system where issues of responsibility and respect for future generations and non-human species are discussed and, at least to some extent, taken into account, this is far from a rosy picture of different actors getting together in search for efficient and democratic measures to mitigate and adapt to climate change. On the contrary, there is an ongoing struggle among actors on different levels concerning the right to take part in defining and addressing global issues, and there is no guarantee that policies will move in the direction of a broad, final consensus on the road towards a fossil-free planet. There is even a world-wide strong coal-lobby as brought into the light by the 'climategate' [6], including powerful politicians like West Virginia Democratic Senator Joe Manchin, so far making Congress block the Biden administration 'Build Back Better' Act, including its long-term phasing-out-fossil-power agenda [7].

However-and not to forget-almost thirty years ago, in the wake of the 1992 Earth Summit in Rio, and the 1996 Habitat II Conference in Istanbul, the world experienced a worldwide, locally based movement addressing 'sustainable development'. The World Bank launched the Urban Partnership initiative, urging city and national officials to mobilize the resources and talents of bilateral organizations, NGOs, academics, corporations, foundations, and individuals to activate carefully selected teams of experts who will work with them to develop strategic frameworks and to chart pathways for long term growth'. The premise was that 'analysis of a successful city should not be one-dimensional, but must include all the elements of livability, productivity, competitiveness and governance': [8] 'The global threats-mainly resource depletion, environmental degradation and climate change-require global partnership. This global partnership has become a central issue for world peace. Global environmental and development policy is the peace policy of the future' [9].

Partnerships in the Habitat II context were then perceived to have 'a very wide scope, encompassing international capacity building programs at the national and subnational levels'. The aim was to empower all interested parties, particularly local authorities, the private sector, the co-operative sector, trade unions, non-governmental and community-based organizations, to enable them to play an effective role in shelter and human settlements planning and management ' / . . /Each Government should ensure the right of all members of its society to take an active part in the affairs of the community in which they live and ensure and encourage participation in policymaking at all levels' [10].

Common arguments in favor of partnership mentioned in the policy-orientated literature then revolved around the concepts synergy, transformation, and budget enlargement, often exemplified by referring to the joint venture between a profit-seeking commercial firm and non-profit organizations like a local government or a charity. An associated negotiation process over the distribution of profits was then perceived to favor private shareholders as well as social ends. However, even at the time of launching the partnership, vision critical voices reminded us that 'partnerships are complex systems with considerable potential but at the same time full of unexpected traps for the unwary' [8].

Gradually, concepts like 'ecological citizen', 'political consumer' and 'moral agent' became commonplace, thus signaling the potential and willingness of individuals and households to change their attitudes and behavior towards sustainable consumption and lifestyles [11,12]. In addition, Extinction Rebellion, Fridays for Future and other action 
initiatives are examples of a world-wide bottom-up movement with growing potential. However, green values, attitudes, and a willingness to change one's consumption behavior do not just emerge out of talk and protest. Inhabitants of the earth live in a global system of capitalism based on fossil-fuel dependent production and consumption that leaves no one free to choose an alternative, but in small pockets of knowledge, time and space. In particular, most people living in the Global South are, during the foreseeable future, strongly dependent on fossil-fuel-based production of energy to increase their living standard, regardless of global agreements on net-zero emissions of $\mathrm{CO}_{2}$. In other words, there is a long way to go from pockets of 'green growth' to potentially 'de-growth' societies $[13,14]$. Still, long-term change in behavior is possible, although in need of substantial support from responsible multi-level, public and private institutions. Considering the complexity of global warming and sustainable development in all their aspects, there is not, and could not be, one ultimate governance fix for securitizing the consequences of climate change related threats. What we have is a patchwork of partly overlapping assemblies, located at different levels and sectors, and representing different spheres of authority. Government institutions establish links to the parallel structures of informal, voluntary associations such as social movements and environmental associations, as well as individuals, households and for-profit companies, that is a system of 'hybrid governance' [2,15].

Although participation and deliberation within the framework of representative institutions could be supportive in the struggle for a low carbon dependent, sustainable society, these mechanisms are still being used for practices dependent on fossil fuel-based economic growth and an ever-increasing excessive consumption in the Global North. Despite this, there is no lack of local counter-initiatives in favor of creating low carbon, sustainable cities and neighborhoods, signposted by catchwords such as 'eco-cities', 'low-carbon cities', 'sustainable cities', 'zero carbon cities', 'green cities', 'just cities', 'transition towns', 'virtual cities', 'Oekostadt', 'healthy cities', 'inclusive cities', etc. In addition, 'slim', 'slow', 'de-growth', and 'Lo-Tek' cities indicate alternatives to the still strong techno-digital strand of urban renewal visions [11].

In its latest report, the Intergovernmental Panel on Climate Change provides an overview of the current state of knowledge and highlights the need for society to handle the huge dual and interlinked challenge of radically reducing the dependency on fossil fuels and preparing for future outbreaks of extreme weather [16]. Mitigation of climate change aims at halting the increase of carbon dioxide in the atmosphere and making a fossil-free future possible, whereas adaptation aims at making society more resilient to the impacts of climate change whatever its root causes, that is reducing damage caused by sudden threats like flooding, heatwaves, droughts and forest fires. The state of knowledge about the historical development and the current situation, as well as credible forecasts about what will happen, are scientifically well founded as a basis for policies and planned activities to mitigate the emissions causing climate change and adapt to contemporary and future impacts and risks, in the direction of making society more secure [17,18].

Unfortunately, however, there is no corresponding knowledge of exactly where, when and with what specific consequences global warming will appear. Nevertheless, mitigation and adaptation are both crucial aspects implying efforts at all levels and sectors of society, that is multi-level, hybrid governance and planning targeted at the reduction of greenhouse gas emissions and risk reduction [2]. The scale of these challenges calls for the state to be strongly involved in multi-scalar securitizing efforts that are coordinated with businesses, non-governmental organizations, citizens and inhabitants at national, regional and local levels. Thus, both mitigation and adaptation are collective security issues characterized by considerable uncertainty concerning policy and measures regarding who should take responsibility for those actions. Notably, with regard to adaptation to extreme events such as flooding, wild-fires and contaminated air, there is no escape, not even for those who still negate or ignore the real human-induced causes of global warming.

Climate change then has to be addressed in a policy framework taking a broad view, acknowledging economic, cultural, social and political dimensions and their complicated 
interrelationships with overall ecological concerns [19]. As once stated by Peter Marcuse: "Sustainability is not enough/ ... / the promotion of "sustainability" may simply encourage the sustaining of the unjust status quo and how the attempt to suggest that everyone has common interests in "sustainable urban development" masks very real conflicts of interest' [20]. Presuming an institutional (dis)order with crisscrossing spheres of governance configurations adapted to context-bound circumstances, it is no wonder that governance research has become strikingly multifaceted in terms of theory, method, and empirical focus. The eight contributions in this Special Issue exemplify innovative ideas and practices related to the challenges of 'sustainability', including climate change and its repercussions on urban settings.

The contribution by Hoelscher, Geirbo, Harboe and Petersen is a critical examination of narratives and practices of resilience and sustainability as applied in various urban settings, especially in the Global South. Arguing that common 'best practice' governance approaches may rather contribute to further crisis, they instead bring attention to 'reflexivity' - a capacity to reconsider core values and practices as crucial for learning by experience in urban policy and practice. Presuming the potential of crisis will become the 'new normal', they argue that policy and analysis of places should instead be examined and practiced with special attention to their implications for values such as 'justice' and 'equity'. Offering a conceptual representation of urban crisis in terms of capacity, necessity, and possibility as a three-dimensional lens, they finally exemplify their approach through snapshots from case studies of cities of Detroit (MI, USA) and Medellin (Colombia).

Granberg and Glover, in their study of three very different cities (Baltimore (MA, USA), Karlstad (Sweden) and Port Vila (Venezuela), highlight the need for addressing the socially unjust, power asymmetrical causes and consequences of how climate risks and vulnerabilities are distributed in terms of justice and power. What priorities and values are at stake? Who decides and how? Who pays and who gains? Although climate change adaptation has primarily been informed by meteorology and related disciplines, this discourse has widened also to include social sciences, subjecting adaptation practices to analysis in terms of policy, governance and implementation. In this article, adaptation of climate change is critically analyzed and discussed in the context of the 'just city' as a key theoretical and normative concept. The authors conclude that the social context with its power and justice asymmetries is crucial to understand the distribution and handling of climate risks and vulnerabilities.

In their study of the South Durban Industrial Basins, Lidskog and Leonard take 'reflexive governance' as their conceptual point of departure, stating that this is a 'new mode of governance', being more inclusive and efficient in responding to complex risks than other approaches. Arguing that there is limited scholarly work on the theoretical and empirical foundations of this governance approach, especially how it may unfold in the Global South, they explore the conditions and constraints for reflexive governance in one of the most polluted regions in southern Africa, also being the scene for contention between residents, industry and government, and the struggle for inclusive democracy during apartheid. The authors find constraints involved in enabling reflexive governance, the most important one being the exclusionary, close alliance between government and industry, overshadowing the protection of social and environmental values, thus again highlighting the need for conceptually informed, context-sensitive analysis.

Offering a multitude of interpretations, 'social sustainability' is a rather vague and misused concept, and therefore has to be meticulously specified to be more than just words in policy and planning practice. Drawing upon Carol Lee Bacchi's methodological approach, Johansson and Gabrielsson present results in their article from a context-sensitive study of proclaimed public policy for social innovations and enterprise in a Swedish city. Policy and research on perceived sustainability policies are loaded with ideological contradictions, here illustrated by projects undergoing policy shifts from stronger, collective sustainability ambitions to 'softer', individual-focused problem representations driven by pragmatic interpretations and the perceived need to make decisions based on a limited range of 
information. The article concludes by emphasizing the need for more critical reflection on how the social dimension is defined when going from words to deeds in implementing ideologically colored concepts like 'sustainable development'.

The article by Fell and Mattson follows up on a critical stance to the longstanding public-private partnership (PPP) hype in much literature on the phenomenon. Using the Doughnut Economics (DE) model as their analytical guide, they conduct a systematic literature review illuminating the shortcomings and limitations of PPP and its potential ability to grapple with unsustainable urban development. The results show that PPPs are often far from inclusive, and instead rather excluding local actors-'the people'-from collaborative participation. Still the model could be useful as a tool to test the scope and depth of local collaborations, for example in the context of international treaties like the Social Development Goals, however, preferably adding a fourth $\mathrm{P}$ - people-to the triple formula. They thus conclude that there is still a long way to go to make PPPs inclusive in terms of various dimensions of social justice.

The article by Guziana brings to the fore another gap in the context of participation policy, practice and research—often advertised under a 'social sustainability' flag—namely who are/are not accepted as citizens in a basic civic and political sense. Worldwide migration makes national policymaking stuttering by not considering the political and ethical concerns about immigrants being defined as citizens, non-citizens, 'nomads' or 'the others'. Taking Sweden as an example, the article demonstrates the lack of inclusive language at local government websites, thereby blurring online information on who are/are not invited to participate. Analysis of information on municipal websites thus reveals that the term citizen is commonly used in a way literally excluding all residents not having acquired formal citizenship. One normative conclusion then is that government authorities should evade using the term 'citizen' when addressing their public, except for instances explicitly requiring formal citizenship.

Taking their point of departure in the notion of 'holistic simplicity', Eimermann, Lindgren and Lundmark explore the willingness of people in the Global North to revise their lifestyles, for example by cultivating their own vegetables, spending more time with relatives, neighbors and friends, as well as reading, walking and doing other everyday activities not dependent on extensive pressure on natural resources. Applying this concept to examine lifestyle patterns in different demographic groups, the article contributes to scholarly debates on the prospects of entering paths towards a 'de-growth' society. Drawing upon quantitative register data as a novel method in this field, they demonstrate how to measure the relative magnitude of holistic simplifiers in a population. Selecting smaller samples for longitudinal studies would make it possible to identify individuals willing to reduce their income, move away from more affluent, densely populated places, reduce their negative impact on the environment and turning to 'downshifting' lifestyles.

Jasmina Nedevska in her 'hypothesis' contribution brings attention to the increasing role of courts in climate litigation as a relatively new, understudied tool in climate governance not least in cases where local and global green movements raise protest against projects causing further exploitation of natural resources and increase of $\mathrm{CO}_{2}$ emissions. The author presents a plan for studying judges' opinions and dissents in the United States exploring the views of U.S. judges on climate litigation conflicts in relation to the ideal of separation of powers: directly, as a political question doctrine, and indirectly, as a doctrine of legal standing. Considering the increasing number of conflicts between the stated goals of $\mathrm{CO}_{2}$ reduction and fossil fuel-dependent industry, the role of courts, not only in the United States, will become even more frequent and thus in need of critical studies.

\section{List of Contributions}

- Hoelscher, K.; Geirbo, H.C.; Harboe, L.; Petersen, S.A. What can we learn from urban crisis? Innovation, flexibility and new urban practice.

- Granberg, M.; Glover, L. The Climate Just City. 
- Lidskog, R.; Leonard, L. Conditions and Constraints for Reflexive Governance of Industrial Risks: The Case of the South Durban Industrial Basin, South Africa.

- Johansson, J.; Gabrielsson, J. Public Policy for Social Innovations and Social Enterprise -What's the Problem Represented to Be?

- Fell, T.; Mattsson, J. The Role of Public-Private Partnerships in Housing as a Potential Contributor to Sustainable Cities and Communities: A Systematic Review.

- Guziana, B. Only for Citizens? Local Political Engagement in Sweden and Inclusiveness of Terms.

- Eimermann, M.; Lindgren, U.; Lundmark, L. Nuancing Holistic Simplicity in Sweden: A Statistical Exploration of Consumption, Age and Gender.

- Nedevska, J. An Attack on the Separation of Powers? Strategic Climate Litigation in the Eyes of U.S. Judges.

Funding: This research received no external funding.

Informed Consent Statement: Not applicable.

Data Availability Statement: Not applicable.

Conflicts of Interest: The authors declare no conflict of interest.

\section{References}

1. Freedom House. Freedom in the World 2021. Democracy under Siege. 2021. Available online: https://freedomhouse.org/report/ freedom-world/2021/democracy-under-siege (accessed on 20 November 2021).

2. Elander, I.; Granberg, M.; Montin, S. Governance and planning in a 'perfect storm': Securitizing climate change, migration and Covid-19 in Sweden. Prog. Plan. 2021, 100634. [CrossRef]

3. World Meteorological Association. State of Climate in 2021: Extreme Events and Major Impacts. 2021. Available online: https:/ / public.wmo.int/en/media/press-release/state-of-climate-2021-extreme-events-and-major-impacts (accessed on 10 December 2021).

4. Climate Action Tracker. 2021. Available online: https://climateactiontracker.org/press/Glasgows-one-degree-2030-credibilitygap-net-zeros-lip-service-to-climate-action / (accessed on 10 December 2021).

5. Monbiot, G. If I Sound Angry, It's Because I am the Guardian. 4 November 2021. Available online: https:/ / mail.google.com/ mail/u/0/\#inbox/FMfcgzGlkjbSMMJZBXrrvqnFLdmjsvjr (accessed on 14 November 2021).

6. Grundmann, R. Climategate and the scientific ethos. Sci. Technol. Hum. Values 2011, 38, 67-93. [CrossRef]

7. Goodell, J. Manchin's Coal Corruption is so much worse than you knew. Rolling Stone. 10 January 2022. Available online: https: //www.rollingstone.com/politics/politics-features/joe-manchin-big-coal-west-virginia-1280922/ (accessed on 16 January 2022).

8. Elander, I. Urban Partnerships; UNESCO; Blackwell Publishing: Hoboken, NJ, USA, 2002; The citation is taken from a document presented at the ISSC-UNESCO Conference in Paris, November 1997. The document is not available on the internet.

9. Töpfer, K. Perspectives on the future: From a northern government. In The Way Forward: Beyond Agenda 21; Dodds, F., Ed.; Earthscan: London, UK, 1997; pp. 238-244.

10. UNCHS (United Nations Centre for Human Settlements). Habitat Agenda and Istanbul Declaration. In Proceedings of the Second United Nations Conference on Human Settlements, Istanbul, Turkey, 3-14 June 1996; United Nations Department of Public Information: New York, NY, USA, 1996.

11. Gustavsson, E.; Elander, I. Behaving Clean without Having to Think Green? Local Eco-Technological and Dialogue-Based, Low-Carbon Projects in Sweden. Urban Technol. 2017, 24, 93-116. [CrossRef]

12. Nielsen, K.S.; Nicholas, K.A.; Creutzig, F.; Dietz, T.; Stern, P.C. The role of high-socioeconomic-status people in locking in or rapidly reducing energy-driven greenhouse gas emissions. In Nature Energy; Springer: Berlin/Heidelberg, Germany, 2021. Available online: https:/ / www.nature.com/articles/s41560-021-00900-y.pdf (accessed on 13 October 2021).

13. Parrique, T.; Barth, J.; Briens, F.; Kerschner, C.; Kraus-Polk, A.; Kuokkanen, A.; Spangenberg, J.H. Decoupling Debunked: Evidence and Arguments against Green Growth as a Sole Strategy for Sustainability; European Environmental Bureau: Brussels, Belgium, 2019. Available online: https:/ / eeb.org/library/decoupling-debunked (accessed on 13 October 2021).

14. Kallis, G.; Demaria, F.; D'Alisa, G. Degrowth. In International Encyclopedia of the Social \& Behavioral Sciences; Wright, J.D., Ed.; Elsevier: Oxford, UK, 2015; Volume 6, pp. 24-30.

15. Vakkuri, J.; Johanson, J.-E. Hybrid Governance, Organisations and Society. Value Creation Perspectives; Routledge: London, UK, 2020.

16. IPCC. The Production Gap Report. 2021. Available online: https://productiongap.org/wpcontent/uploads/2021/10/PGR2021_ web_rev.pdf (accessed on 20 October 2021).

17. Low, N. Being a Planner in Society. For People, Planet, Place; Edward Elgar: Cheltenham, UK, 2021.

18. Dryzek, J.; Pickering, J. The Politics of the Anthropocene; Oxford University Press: Oxford, UK, 2019. 
19. Lidskog, R.; Elander, I. Addressing climate change democratically: Multi-level governance, transnational networks and governmental structures. Sustain. Dev. 2010, 18, 32-41. [CrossRef]

20. Marcuse, P. Sustainability is not enough. Environ. Urban. 1998, 10, 103-112. [CrossRef] 